\title{
Comparative evaluation of hydrophilic bases for improved delivery of Benzoic acid and Salicylic acid in antimicrobial ointment
}

\author{
*Oyedele, A. O., and Akinkunmi, E. O. \\ Department of Pharmaceutics, Faculty of Pharmacy, Obafemi Awolowo University, Ile-Ife, Nigeria \\ *Correspondence to: aoyedele@oauife.edu.ng
}

\begin{abstract}
:
Background: Benzoic acid (BA) and salicylic acid (SA) combined are used as choice topical treatment for fungal and bacterial infections but their delivery is affected by ointment vehicle, among other factors. With aim to achieve improved release and antimicrobial activity in ointment formulation of these medicaments through selection of more efficient vehicle(s), this study comparatively evaluated prospective alternatives to the compendium-specified base for delivery potential and relevant physical properties.

Methodology: Water-sorption capacity, rheological characteristics and heat-tolerance limits of six hydrophilic bases [hydrous ointment (HO), hydrous sheabutter (HS), neat sheabutter (NS), lanolin anhydrous (LA), lanolin hydrous ( $\mathrm{LH})$, and emulsifying ointment (EO)] and their ointment products containing $1,2,3$, or $6 \% \mathrm{w} / \mathrm{w}$ of $\mathrm{BA}$ or SA were determined. Drug delivery propensity of the products was evaluated by agar diffusion colorimetric assay, while their antimicrobial activities were determined by hole-in-plate agar diffusion assay against selected type organisms (Bacillus subtilis, Staphylococcus aureus, Escherichia coli, Pseudomonas aeruginosa, Candida albicans and Candida pseudotropicalis).

Results: BA was released in relatively larger quantity and demonstrated greater antimicrobial activity than SA in most bases. The released quantities of each medicament correlated directly with concentration and antimicrobial activities. The rates and extents of drug release followed a similar trend in different vehicles namely, $\mathrm{HO}>\mathrm{HS}>\mathrm{NS} \geq \mathrm{EO}>\mathrm{LA} \approx \mathrm{LH}$. Water number of base, ointment preparation method, viscosity, or heat-tolerance showed no influence on drug release or antimicrobial activity.

Conclusion: $\mathrm{HO}$ and HS are better vehicles for delivery of BA and SA in ointment than EO which is the prototypical base.
\end{abstract}

Keywords: Benzoic acid, Salicylic acid, Antimicrobial activity, Ointment base, Delivery factors

Received May 15, 2020; Revised July 16, 2020; Accepted July 18, 2020

Copyright 2021 AJCEM Open Access. This article is licensed and distributed under the terms of the Creative Commons Attrition 4.0 International License <a rel="license" href="http://creativecommons.org/licenses/by/4.0/", which permits unrestricted use, distribution and reproduction in any medium, provided credit is given to the original author(s) and the source. Editor-in-Chief: Prof. S. S. Taiwo

\section{Évaluation comparative des bases hydrophiles pour une meilleure administration d'acide benzoïque et d'acide salicylique dans une pommade antimicrobienne}

\author{
*Oyedele, A. O., et Akinkunmi, E. O. \\ Département de pharmacie, Faculté de pharmacie, Université Obafemi Awolowo, Ile-Ife, Nigéria \\ *Correspondance à: aoyedele@oauife.edu.ng
}

\section{Abstrait:}

Contexte: L'acide benzoïque (BA) et l'acide salicylique (SA) combinés sont utilisés comme traitement topique de choix pour les infections fongiques et bactériennes, mais leur administration est affectée par le véhicule de la pommade, entre autres facteurs. Dans le but d'améliorer la libération et l'activité antimicrobienne dans la formulation de pommade de ces médicaments grâce à la sélection de véhicules plus efficaces, cette étude a évalué comparativement des alternatives potentielles à la base spécifiée dans le compendium pour le potentiel d'administration et les propriétés physiques pertinentes.

Méthodologie: Capacité de sorption de l'eau, caractéristiques rhéologiques et limites de tolérance à la chaleur de six bases hydrophiles [pommade hydratée (HO), beurre de karité hydraté (HS), beurre de karité pur (NS), lanoline anhydre (LA), lanoline hydratée (LH), et onguent émulsifiant (EO)] et leurs produits de pommade contenant $1,2,3$ ou $6 \% \mathrm{p} / \mathrm{p}$ de BA ou SA ont été déterminés. La propension à l'administration de médicaments 
des produits a été évaluée par un essai colorimétrique de diffusion sur gélose, tandis que leurs activités antimicrobiennes ont été déterminées par un essai de diffusion sur gélose en plaque contre des organismes de type sélectionné (Bacillus subtilis, Staphylococcus aureus, Escherichia coli, Pseudomonas aeruginosa, Candida albicans et Candida pseudotropicalis).

Résultats: BA a été libéré en quantité relativement plus grande et a démontré une plus grande activité antimicrobienne que SA dans la plupart des bases. Les quantités libérées de chaque médicament étaient directement liées à la concentration et aux activités antimicrobiennes. Les taux et l'étendue de la libération de médicaments ont suivi une tendance similaire dans différents véhicules, à savoir $H O>H S>N S \geq E O>L A \approx L H$. Le nombre d'eau de base, la méthode de préparation de la pommade, la viscosité ou la tolérance à la chaleur n'ont montré aucune influence sur la libération du médicament ou l'activité antimicrobienne.

Conclusion: $\mathrm{HO}$ et HS sont de meilleurs véhicules pour la livraison de BA et SA en onguent que EO qui est la base prototypique.

Mots-clés: acide benzoïque, acide salicylique, activité antimicrobienne, base de pommade, facteurs de délivrance

\section{Introduction:}

Ointments are semisolid pharmaceutical dosage forms designed for application to human skin or to the surface of the eye or used nasally, vaginally or rectally for topical effect. Most ointments are used for the effects of the therapeutic agents they contain. Non-medicated ointments, on the other hand, are used for physical effects they provide on skin as protectants, emollients or lubricants. They are known as ointment bases and serve in medicated ointments as vehicles (carriers) for the therapeutic agents (1).

Benzoic acid is a crystalline, white or colourless solid organic compound (empirical formula: $\mathrm{C}_{6} \mathrm{H}_{5} \mathrm{CO}_{2} \mathrm{H}$ ), slightly soluble in water $\left(3.44 \mathrm{~g} / \mathrm{L}\right.$ at $\left.25^{\circ} \mathrm{C}\right)$. It is the simplest aromatic carboxylic acid also known as phenylcarbo xylic acid, phenylmethanoic acid, benzene caboxylic acid, or carboxybenzene (2). Benzoic acid as well as its salts and esters called benzoates possess antibacterial and antifungal properties and are included as ingredients of cosmetic products, used as preservative in foods and pharmaceutical preparations as preservative or as antiseptic agents. Salicylic acid, on the other hand, is a colourless or white crystalline, aromatic organic solid compound with empirical formula, $\mathrm{C}_{6} \mathrm{H}_{4}(\mathrm{OH}) \mathrm{COOH}$, where the hydroxyl group is ortho to the carboxyl group. Salicylic acid is a lipophilic monohydroxybenzoic acid, that is also known as 2-hydroxybenzoic acid. It is a poorly water-soluble phenolic acid (solubility: $2 \mathrm{~g} / \mathrm{L}$ at $20^{\circ} \mathrm{C}$ ) (3). Salts and esters of salicylic acid are called salicylates and have medicinal (analgesic, anti-inflammatory) value. Salicylic acid, as a medication, is commonly used topically (in ointment or cream) for its keratolytic, bacteriostatic and fungicidal properties, to treat warts, psoriasis, acne, ringworm, dandruff, and ichthyosis in pharmaceutical or skincare products (4).

The combined use of benzoic acid and salicylic acid in ointment preparation at 6 and $3 \%$ concentrations respectively, known as Whitfield or compound benzoic acid ointment, was on the World Health Organization (WHO) list of essential medicines until the $16^{\text {th }}$ update of $2009(5,6)$. Its removal from the 2011 list onward was not attributed to any safety reason or untoward effect but to availability of competitive alternative (7). Earlier, there had been a suggestion to enhance the release of Whitfield ointment's medicaments by the use of a natural base plus surfactants as an alternative to emulsifying ointment, the vehicle recommended by official compendium (8).

The base used to prepare a semisolid medication exerts considerable control over the release and hence the therapeutic action of the medicament it carries. Two general approaches are used for topical preparations to maximize absorption of the active ingredient from the vehicle; inclusion of an agent that affects the barrier function of the epidermis (9), or employment and development of a vehicle with physical characteristics that favour diffusion of the drug from the vehicle to the skin using an experimental procedure that measures drug release from the vehicle, from which the most suitable base is selected. In the latter approach however, inclusion of surfactant into semisolid base could contribute multifarious effects; sometimes improving drug release $(10,11)$, reducing release $(12,13)$, or not affecting drug release at all (14).

Hydrophilic ointment bases are those permitting addition of water (or aqueous solutions) due to their water-miscibility or water absorption capacity. Their advantages over hydrophobic bases include being waterwashable (water-removable), compatible with normal skin functions and exhibiting more efficient or rapid drug delivery properties even with exclusion of surfactant $(1,15)$. The aim of this study, therefore, was to comparatively evaluate five hydrophilic ointment bases as prospective alternatives for improved delivery of benzoic acid and salicylic acid from dispersion ointment formulation, and correlate the findings with concurrently determined antimicrobial activities of the medicaments in order to elucidate the factors 
that may contribute to enhanced drug delivery function.

\section{Materials and method:}

\section{Study setting}

The study was carried out at the postgraduate pharmaceutical technology and pharmaceutical microbiology laboratories of the Department of Pharmaceutics, Faculty of Pharmacy, Obafemi Awolowo University, IleIfe, Nigeria.

\section{Materials}

Materials used in the study were Benzoic acid (Fig 1A) and salicylic acid (Fig 1B) (May and Baker, Dagenham, England) each screened through $180 \mu \mathrm{m}$-aperture (mesh no. 85) standard sieve (Okhard Machine Tools Co. Ltd, Lagos Nigeria); emulsifying wax (Evans Medical Ltd. Liverpool); liquid, white soft, and hard paraffin (William
Ransom and Sons Plc. England); lanolin anhydrous, and wool alcohols (BDH, Poole, England).

Hydrophilic ointment bases studied were hydrous ointment (HO), hydrous sheabutter (HS), neat sheabutter (NS), lanolin anhydrous (LA), lanolin hydrous (LH), and emulsifying ointment (EO), having composition as given in Table 1 . Neat sheabutter was obtained by hot $\left(60^{\circ} \mathrm{C}\right)$ filtration processing of natural sheabutter (16) procured at Shaki market, Oyo State, Nigeria, while lanolin anhydrous was as obtained from its manufacturer. Emulsifying ointment BP and hydrous ointment BP were prepared according to the compendium guidelines (17). Microbiological culture media used were Mueller-Hinton (MH), Nutrient agar (NA), and Sabouraud's Dextrose agar (Rapid Labs Ltd, Colchester Essex, UK) which were prepared according to the manufacturers' instructions.

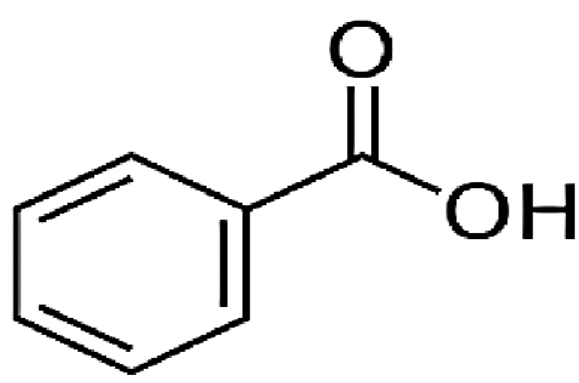

Figure 1A: Chemical structure of benzoic acid molecular weight: $122.12 \mathrm{~g} / \mathrm{mol}$

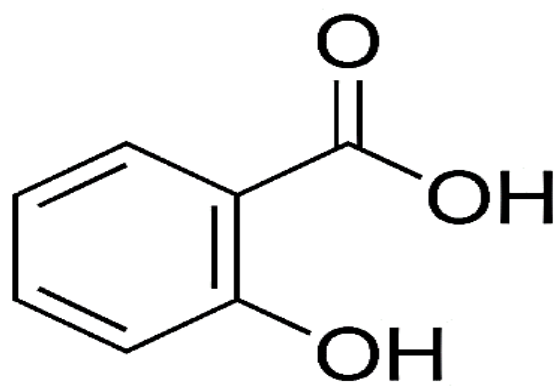

Figure 1B: Chemical structure of salicylic acid molecular weight: $138.12 \mathrm{~g} / \mathrm{mol}$

Table 1: Composition of ointment bases and of Whitfield ointment

\begin{tabular}{|c|c|c|c|c|c|}
\hline \multirow[b]{2}{*}{ Ingredients } & \multicolumn{4}{|c|}{$\begin{array}{c}\text { Name of Ointment Base/ } \\
\text { Ingredient Concentrations }(\% \mathrm{w} / \mathrm{w})\end{array}$} & \multirow{2}{*}{$\begin{array}{l}\text { Whitfield Ointment } \\
\text { BP composition } \\
(\% w / w)\end{array}$} \\
\hline & $\begin{array}{l}\text { Hydrous } \\
\text { ointment BP }\end{array}$ & $\begin{array}{l}\text { Emulsifying } \\
\text { ointment } \mathrm{BP}\end{array}$ & $\begin{array}{l}\text { Lanolin } \\
\text { hydrous }\end{array}$ & $\begin{array}{l}\text { Hydrous } \\
\text { sheabutter }\end{array}$ & \\
\hline Liquid paraffin & 30 & 20 & - & - & 18.2 \\
\hline Hard paraffin & 12 & - & - & - & - \\
\hline White soft paraffin & 5 & 50 & - & - & 45.5 \\
\hline Wool alcohols & 3 & - & - & - & - \\
\hline Emulsifying wax & - & 30 & - & - & 27.3 \\
\hline Lanolin anhydrous & - & - & 70 & - & - \\
\hline Neat sheabutter & - & - & - & 70 & - \\
\hline Water (purified) & 50 & - & 30 & 30 & - \\
\hline Benzoic acid & - & - & - & - & 6.0 \\
\hline Salicylic acid & - & - & - & - & 3.0 \\
\hline
\end{tabular}


Determination of water number of ointment bases

The water number (water-sorption capacity) of the six ointment bases ( $10 \mathrm{~g}$ samples) was determined at the ambient temperature $\left(30 \pm 2^{\circ} \mathrm{C}\right)$ using the pharmacopeial method described for hydrous wool fat (17) and expressed conventionally as the volume of water $(\mathrm{mL})$ absorbed per $100 \mathrm{~g}$ of base.

\section{Preparation of medicated ointments}

Two batches ( $100 \mathrm{~g}$ each) of medicated ointment preparations were made with each ointment base using two different methods; levigation and fusion. In the levigation method, the medicament [benzoic acid at $1,2,3$, or $6 \%$; and salicylic acid at 1,2 , or $3 \%(\mathrm{w} / \mathrm{w})$ concentrations] was incorporated by mixing into the ointment base with spatula on glazed porcelain tile at the ambient temperature $\left(30 \pm 2^{\circ} \mathrm{C}\right)$ until a uniform preparation was attained. In the fusion method, however, mild heat $\left(\leq 50^{\circ} \mathrm{C}\right)$ was applied to soften or melt the base, which facilitated subsequent incorporation of the medicament, followed by constant stirring of the preparation while allowing it to cool until congealed (18). The medicated ointment samples, packaged ( $20 \mathrm{~g}$ aliquots) in screw-cap (airtight) ointment jars were subsequently assessed for their physical stability and release properties as follows;

\section{Viscometric testing of ointments}

Viscosity measurements were carried out on the bland and medicated ointment samples ( $20 \mathrm{~g}$ each) at the ambient temperature $\left(30 \pm 2{ }^{\circ} \mathrm{C}\right)$ using a Rion VT-04F viscotester, spindle no. 2 (Rion Co. Ltd, Tokyo Japan). The yield point value (initial peak) and viscosity of each sample were determined for 30s. Any physical consistency changes in the sample under test were noted.

\begin{abstract}
Heat-tolerance limit testing of ointments Softening and melting temperatures of bland bases and of completed medicated ointments, and the congealing temperature values on cooling to ambient temperatures after melting, were determined using the method for suppository bases described by Adegboye and Itiola (19). Softening point was the temperature at which the sample began to liquefy, while melting point was the temperature of complete liquefaction. The mean and standard deviation (SD) of four determinations were recorded.
\end{abstract}

\section{Determination of in vitro drug-release from ointments}

The drug release propensity of medicated ointments was determined by the agar diffusion colorimetric assay earlier described $(20,21)$ and modified as follows; To $20 \mathrm{~mL}$ of
$1 \%(\mathrm{w} / \mathrm{v})$ bacteriological agar gel previously melted and cooled to $45^{\circ} \mathrm{C}$ was added and mixed gently $0.5 \mathrm{~mL}$ of appropriate colourindicator solution, and poured into clean 90$\mathrm{mm}$ diameter Petri dishes and allowed to set. Five percent $(\mathrm{w} / \mathrm{v})$ aqueous solution of bromocresol green and ferric chloride served as the appropriate indicators for testing ointments containing benzoic acid and salicylic acid respectively. After $30 \mathrm{~min}$, three equidistant cups $(8.0 \mathrm{~mm}$ in diameter) were made into the agar plate using a sterile cork-borer and $0.2 \mathrm{~mL}$ (approximately $170 \mathrm{mg}$ ) of medicated ointment sample was extruded from a $5 \mathrm{~mL}$ glass syringe into each agar cup (triplicate experiments), placed such that it made uniform contact with the agar gel.

The plates were incubated at $37^{\circ} \mathrm{C}$ in aerobic incubator. The diameters of colourzone changes produced around each cup as the medicament was released and diffused through agar from the ointment sample were measured at predetermined time intervals; 10,20 , and 30 min intervals during the $1^{\text {st }}$, $2^{\text {nd }}$, and until the $6^{\text {th }}$ hours respectively, and then hourly, 2-hourly, and 4-hourly intervals until the $10^{\text {th }}, 16^{\text {th }}$, and $24^{\text {th }}$ hours respecttively. The area of coloured zones was calculated from the mean diameter of each zone to indicate extent of the medicament released from ointment at the various datasampling times from which the rate of release was calculated. The release rate of benzoic acid or salicylic acid from each medicated ointment preparation in each base was determined as the slope value in the regression line equation of the plot of diffusion-zone size of the medicament versus the square-root of time (22).

\section{Determination of antimicrobial activity of the ointment products}

Test microorganisms and culture conditions The test organisms used were Bacillus subtilis (NCTC 8236), Staphylococcus aureus (NCTC 6571), Escherichia coli (ATCC 25922), Pseudomonas aeruginosa (ATCC 10145), Candida albicans (ATCC 24433), and Candida pseudotropicalis (NCYC 6). The bacterial strains were grown on Nutrient agar slopes at $37^{\circ} \mathrm{C}$ for 24 hours while the fungal cultures were grown on Sabouraud's Dextrose agar slopes for 48 hours at $25^{\circ} \mathrm{C}$. The organisms were maintained on slopes and sub-cultured weekly.

\section{Screening for antibacterial and antifungal activities}

For antibacterial activity testing, 0.5 $\mathrm{mL}$ of 0.5 McFarland standards turbidity suspension (approx. $1 \times 10^{8} \mathrm{CFU} / \mathrm{mL}$ ) of each bacterial strain was inoculated and spread evenly on the surface of over-dried Mueller- 
Hinton ( $\mathrm{MH}$ ) agar plates while for antifungal activity testing, $48 \mathrm{~h}$ surface culture of each fungal strain on Sabouraud's Dextrose Agar (SDA) slopes that were washed off and diluted to an inoculum size of $10^{7} \mathrm{CFU} / \mathrm{mL}$ was used. $0.5 \mathrm{~mL}$ of this suspension was evenly spread on the surface of over-dried SDA plates.

The hole-in-plate agar diffusion method (23) was used to assess the anti- microbial activities of ointment products con- taining benzoic acid or salicylic acid (at $1,2,3,4.5$, or $6 \% \mathrm{w} / \mathrm{w}$ concentrations of the medi- cament) made by levigation using different hydrophilic bases against each test organism. A $10 \mathrm{~g}$ sample of each of the six medicated ointments was made for testing, Whitfield ointment (Table 1 ) serving as comparator ointment. Three equidistant wells ( $8 \mathrm{~mm}$ dia- meter each) were cut into each prepared (inoculated) agar plate using a sterile cork-borer, and approximately $170 \mathrm{mg}$ of medi- cated ointment sample for testing ( $0.2 \mathrm{~mL}$ extruded from a $5 \mathrm{~mL}$ glass syringe) was int- roduced into each well for each ointment (test was done in triplicate). The plates were refrigerated $\left(4^{\circ} \mathrm{C}\right)$ for 1 hour to allow for diffusion of incorporated medicament and then incubated at $37^{\circ} \mathrm{C}$ aerobically for $24 \mathrm{hr}$ for bacteria and $25^{\circ} \mathrm{C}$ for $48 \mathrm{~h}$ for fungi. The diameters of inhibition zones (in $\mathrm{mm}$ ) were measured. Bland ointment bases were eva- luated alongside the medicated ointments as negative control. Following the same testing procedure, the antimicrobial activity of aqu- eous solution of benzoic acid and salicylic acid, each prepared in $50 \% \mathrm{v} / \mathrm{v}$ aqueous methanol as solvent (at $0.5,1,2$, or $4 \% \mathrm{w} / \mathrm{v}$ concentrations respectively as positive cont- rols), was also evaluated against each bac- terial and fungal strains. A $100 \mu \mathrm{L}$ sample of each test solution was placed similarly (in triplicate) in equidistant wells of appropriately prepared agar plates for testing. The $50 \%$ aqueous methanol solvent alone was eva- luated as negative control.

\section{Data analysis}

The minimum inhibitory concentration (MIC) of benzoic acid and salicylic acid against each test organism was determined by linear regression analysis of the inhibition zone sizes produced by each medicament over graded concentrations in aqueous methanol solution, plotted against the logarithm of concentration (24). The extents of release of the medicaments from different ointment bases in $24 \mathrm{~h}$, and correlation of the extents against medicament concentration, were evaluated for significance using $t$ test. Factors influencing the release of medicament from the bases were investigated by Spearman's rank order correlation of the release rate data compared against each of four factors namely; the preparation method, viscosity under shear of the $3 \%$ medicated ointments batch, the water number, and softening point of the bases. Significance was accepted at $p<0.05$ level.

\section{Results:}

Water number and viscosity of ointments Table 2 shows the water number of non-medicated bases as well as viscosity of the bland and medicated ointments. Among the bland bases, emulsifying ointment (EO) demonstrated the highest water-sorption capacity, with unlimited absorption upon step wise addition of water until it converted, in the process, to fluid oil-in-water emulsion. Lanolin anhydrous (LA) exhibited the next highest water number $(205.0 \mathrm{~mL} / 100 \mathrm{~g})$, while hydrous sheabutter (HS) showed the least water number $(10.5 \mathrm{~mL} / 100 \mathrm{~g})$.

All the six ointment bases exhibited thixotropic (Bingham plastic) character with different yield point stress values: hydrous ointment (HO) 50; hydrous sheabutter (HS) 60; neat sheabutter (NS) 150; lanolin anhydrous (LA) 75; lanolin hydrous (LH) 80; and emulsifying ointment (EO) 110 Pa.s, followed by decline to a constant viscosity over $15-20$ s of measurement (Fig 2), becoming steady on the constant apparent viscosity values of hydrous ointment ( $\mathrm{HO}) 12$, hydrous sheabutter (HS) 10, neat sheabutter (NS) 45, lanolin anhydrous (LA) 40, lanolin hydrous (LH) 60, and emulsifying ointment (EO) 60 Pa.s (Table 2).

Incorporation of the medicaments (benzoic acid or salicylic acid) into the bases mostly resulted in ointment products of lower viscosity than the bland base. Exception to this general observation occurred with $\mathrm{HO}$ and HS, medicated ointment products of which exhibited higher viscosities than those of the respective bland vehicles. However, on occasions, HS base or its medicated product suffered texture-breakdown under levigation or fusion processing, accompanied by marked reduction in viscosity (Table 2 ). 


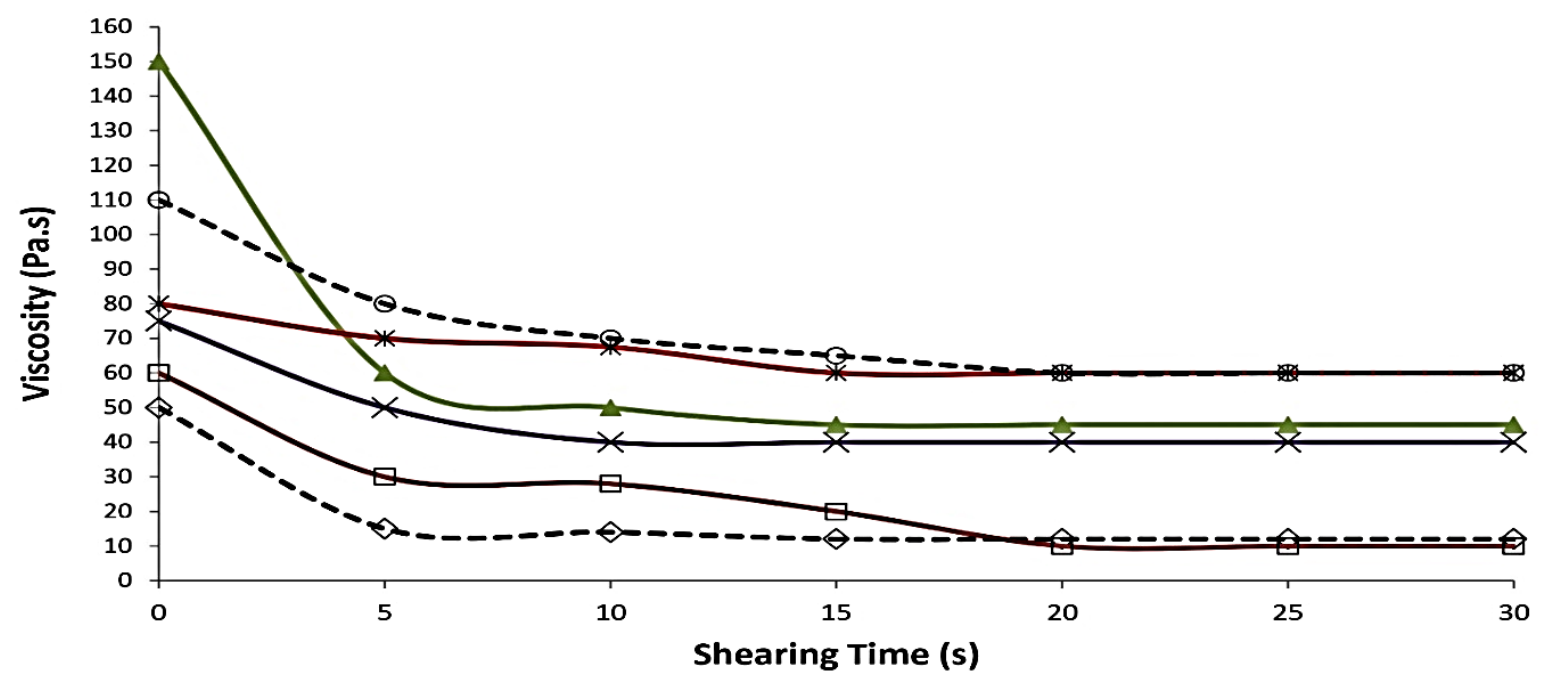

Figure 2: Viscosity Profile of Ointment Bases

$\begin{array}{lll}-\diamond-\text { Hydrous Ointment (HO) } & - \text { Hydrous Sheabutter (HS) } & - \text { Neat Sheabutter (NS) } \\ \rightarrow \text { Lanolin Anhydrous (LA) } & \rightarrow \text { Lanolin Hydrous (LH) } & -\ominus-\text { Emulsifying Ointment (EO) }\end{array}$

Table 2: Water number and viscosity of ointments

\begin{tabular}{|c|c|c|c|c|c|c|}
\hline \multirow[b]{3}{*}{$\begin{array}{l}\text { Ointment Base/ } \\
\text { Its Water Number (mL/100g)* }\end{array}$} & \multirow{3}{*}{\multicolumn{2}{|c|}{$\begin{array}{r}\text { Concentration of } \\
\text { Medicament } \\
(\% \mathrm{ow} / \mathrm{w})\end{array}$}} & \multicolumn{3}{|c|}{$\begin{array}{l}\text { Medicament/ Preparation Method/ } \\
\text { Apparent Viscosity of Ointment (Pa.s) }\end{array}$} & \\
\hline & & & \multicolumn{2}{|c|}{ Benzoic acid } & Salicylic acid & \\
\hline & & & Levigation & Fusion & Levigation & Fusion \\
\hline \multirow{5}{*}{$\begin{array}{l}\text { Hydrous Ointment BP } \\
107.5 \pm 2.9\end{array}$} & Ointment base & 0 & $\mathbf{a} 12$ & & & \\
\hline & 8 & 1 & 10 & 15 & 13 & 20 \\
\hline & 岕 & 2 & 15 & 15 & 13 & 20 \\
\hline & 음 틑 & 3 & 15 & 15 & 13 & 20 \\
\hline & $\sum$ & 6 & 15 & 15 & - & - \\
\hline \multirow{5}{*}{$\begin{array}{l}\text { Hydrous Sheabutter } \\
10.5 \pm 1.0\end{array}$} & Ointment base & 0 & 10 & & & \\
\hline & 颍 든 & 1 & b10 & 40 & 70 & 40 \\
\hline & 岕 & 2 & $b_{10}$ & 40 & $b_{10}$ & 40 \\
\hline & 응 듣 & 3 & $b_{10}$ & 65 & $b_{10}$ & $\mathrm{~b}_{10}$ \\
\hline & $\sum^{\infty} \overline{0}$ & 6 & b10 & 55 & - & - \\
\hline \multirow{5}{*}{$\begin{array}{l}\text { Neat Sheabutter } \\
117.5 \pm 2.9\end{array}$} & Ointment base & 0 & $a 45$ & & & \\
\hline & 召 & 1 & 40 & 40 & 40 & 40 \\
\hline & 亗 氚 & 2 & 30 & 30 & 40 & 40 \\
\hline & 음 틀 & 3 & 30 & 17 & 35 & 35 \\
\hline & $\sum \overline{0}$ & 6 & 25 & 15 & - & - \\
\hline \multirow{5}{*}{$\begin{array}{l}\text { Lanolin Anhydrous } \\
205.0 \pm 4.1\end{array}$} & Ointment base & 0 & .40 & & & \\
\hline & g & 1 & 35 & 40 & 35 & 40 \\
\hline & 苞 & 2 & 30 & 40 & 30 & 40 \\
\hline & 늠 흗 & 3 & 28 & 35 & 23 & 35 \\
\hline & $\sum \overline{0}$ & 6 & 25 & 30 & - & - \\
\hline \multirow{5}{*}{$\begin{array}{l}\text { Lanolin Hydrous } \\
170.0 \pm 9.1\end{array}$} & Ointment base & 0 & .60 & & & \\
\hline & 몽듬 & 1 & 45 & 50 & 50 & 55 \\
\hline & 苛 Ф & 2 & 40 & 45 & 50 & 25 \\
\hline & 음 듣 & 3 & 40 & 40 & 40 & 15 \\
\hline & $\sum \overline{0}$ & 6 & 30 & 33 & - & - \\
\hline \multirow{5}{*}{$\begin{array}{l}\text { Emulsifying Ointment BP } \\
\text { Indefinite** }\end{array}$} & Ointment base & 0 & .60 & & & \\
\hline & 몸닫 & 1 & 50 & 45 & 30 & 40 \\
\hline & 荧 产 & 2 & 40 & 45 & 30 & 35 \\
\hline & 음 돋 & 3 & 35 & 38 & 25 & 35 \\
\hline & $\sum \overline{0}$ & 6 & 35 & 38 & - & - \\
\hline
\end{tabular}

\section{Heat-stress vulnerability of ointments}

Heat-tolerance thresholds of the ointment bases varied, ranging from the $37^{\circ} \mathrm{C}$ softening point of neat sheabutter (NS) and of emulsifying ointment (EO) to $56^{\circ} \mathrm{C}$, the melting point of lanolin hydrous (LH). But their softening points were very close to their respective congealing point values (within $\pm 1^{\circ} \mathrm{C}$ ) except for hydrous sheabutter (HS)
(Table 3).

Incorporation of medicament into each base caused a drop to lower values of heat-tolerance limit of the resultant ointment products; except lanolin anhydrous (LA) with $36^{\circ} \mathrm{C}$ softening point of the bland base against (nearly the same) 35 or $36^{\circ} \mathrm{C}$ softening point value of its medicated ointments, and $39^{\circ} \mathrm{C}$ melting point of the non-med- 
Table 3: Heat-stress vulnerability of ointments

\begin{tabular}{|c|c|c|c|c|c|c|}
\hline \multirow[b]{3}{*}{ Ointment Base } & \multirow[b]{3}{*}{$\begin{array}{l}\text { Vulnerability } \\
\text { Parameters }\end{array}$} & \multirow[b]{3}{*}{$\begin{array}{l}\text { Vulnerability Point for } \\
\text { Ointment Base }\left({ }^{\circ} \mathrm{C}\right)^{\mathrm{a}}\end{array}$} & \multicolumn{4}{|c|}{$\begin{array}{c}\text { Ointment Preparation Method/ } \\
\text { Active Principle }(3 \% \mathrm{w} / \mathrm{w}) / \text { Vulnerability Point }\left({ }^{\circ} \mathrm{C}\right)^{\mathrm{a}}\end{array}$} \\
\hline & & & Levigation & Fusion & Levigation & Fusion \\
\hline & & & \multicolumn{2}{|c|}{ Benzoic acid } & \multicolumn{2}{|c|}{ Salicylic acid } \\
\hline \multirow{3}{*}{$\begin{array}{l}\text { Hydrous } \\
\text { ointment BP }\end{array}$} & Softening & $41 \pm 0.7$ & $34 \pm 0.3$ & $34 \pm 0.5$ & $35 \pm 0.3$ & $35 \pm 0.3$ \\
\hline & Congealing & $42 \pm 0.7$ & $38 \pm 0.5$ & $38 \pm 0.3$ & $39 \pm 0.3$ & $37 \pm 0.3$ \\
\hline & Melting & $47 \pm 0.3$ & $39 \pm 0.5$ & $39 \pm 0.3$ & $43 \pm 0.5$ & $41 \pm 0.3$ \\
\hline \multirow{3}{*}{$\begin{array}{l}\text { Hydrous } \\
\text { Sheabutter }\end{array}$} & Softening & $s_{38} \pm 0.4$ & $v_{33} \pm 0.5$ & $v_{31} \pm 0.3$ & $u_{32} \pm 0.3$ & $v_{32} \pm 0.3$ \\
\hline & Congealing & $u_{28} \pm 0.4$ & $u_{23} \pm 0.5$ & $u_{22} \pm 0.5$ & $u_{23} \pm 0.3$ & $u_{22} \pm 0.3$ \\
\hline & Melting & $42 \pm 0.5$ & $34 \pm 0.5$ & $33 \pm 0.3$ & $37 \pm 0.5$ & $36 \pm 0.3$ \\
\hline \multirow{3}{*}{$\begin{array}{l}\text { Neat } \\
\text { Sheabutter }\end{array}$} & Softening & $s_{37} \pm 0.3$ & $v_{32} \pm 0.2$ & $v_{32} \pm 0.2$ & $v_{33} \pm 0.3$ & $v_{33} \pm 0.3$ \\
\hline & Congealing & $u_{37} \pm 0.3$ & $u_{26} \pm 0.2$ & $v_{24} \pm 0.2$ & $v_{23} \pm 0.3$ & $v_{22} \pm 0.3$ \\
\hline & Melting & $39 \pm 0.3$ & $33 \pm 0.2$ & $35 \pm 0.2$ & $37 \pm 0.3$ & $37 \pm 0.3$ \\
\hline \multirow{3}{*}{$\begin{array}{l}\text { Lanolin } \\
\text { Anhydrous }\end{array}$} & Softening & $36 \pm 0.3$ & $36 \pm 0.3$ & $35 \pm 0.3$ & $35 \pm 0.3$ & $36 \pm 0.3$ \\
\hline & Congealing & $37 \pm 0.3$ & $35 \pm 0.3$ & $35 \pm 0.3$ & $36 \pm 0.3$ & $35 \pm 0.3$ \\
\hline & Melting & $39 \pm 0.3$ & $42 \pm 0.5$ & $42 \pm 0.5$ & $42 \pm 0.3$ & $41 \pm 0.3$ \\
\hline \multirow{3}{*}{$\begin{array}{l}\text { Lanolin } \\
\text { Hydrous }\end{array}$} & Softening & $45 \pm 0.7$ & $37 \pm 0.5$ & $35 \pm 0.3$ & $37 \pm 0.3$ & $37 \pm 0.3$ \\
\hline & Congealing & $47 \pm 0.5$ & $36 \pm 0.3$ & $34 \pm 0.3$ & $35 \pm 0.3$ & $36 \pm 0.3$ \\
\hline & Melting & $56 \pm 0.8$ & $42 \pm 0.5$ & $41 \pm 0.5$ & $46 \pm 0.5$ & $46 \pm 0.5$ \\
\hline \multirow{3}{*}{$\begin{array}{l}\text { Emulsifying } \\
\text { Ointment BP }\end{array}$} & Softening & $37 \pm 0.3$ & $34 \pm 0.3$ & $34 \pm 0.3$ & $34 \pm 0.5$ & $35 \pm 0.5$ \\
\hline & Congealing & $39 \pm 0.3$ & $36 \pm 0.3$ & $36 \pm 0.5$ & $39 \pm 0.3$ & $39 \pm 0.5$ \\
\hline & Melting & $43 \pm 0.3$ & $38 \pm 0.7$ & $41 \pm 0.5$ & $39 \pm 0.4$ & $40 \pm 0.3$ \\
\hline
\end{tabular}

Values represent the mean \pm SD

sStable base form

icated base versus $41-42^{\circ} \mathrm{C}$ melting point values of its medicated ointments, showing an increase following medicament incorporation (Table 3 ). Under mild but protracted heating $\left(39-42^{\circ} \mathrm{C}\right.$ for $\left.10-15 \mathrm{~min}\right)$ required to soften or melt HS or NS base for incorporation of medicament, polymorphic transformation of the base often occurred, resulting in weaker, unstable texture of the base, which gave ointment products of a lower congealing point $\left(\leq 26^{\circ} \mathrm{C}\right)$ than that of the precursor base (Table 3 ).
Direct correlation of medicament concentration with release

The amounts of each medicament released in 24 hours from each medicated ointment base were in direct trend with the medicament concentrations; 1,2 , and $3 \%$ respectively (Figs 3 and 4 ). The increase of the amounts of each medicament released in 24 hours with the stepwise increase in medicament concentration in benzoic acid ointments (from 1 to $6 \% \mathrm{w} / \mathrm{w}$ ), and in Salicylic acid ointments (from 1 to $3 \% \mathrm{w} / \mathrm{w}$ ) was, in each case, significant at $p<0.01$.

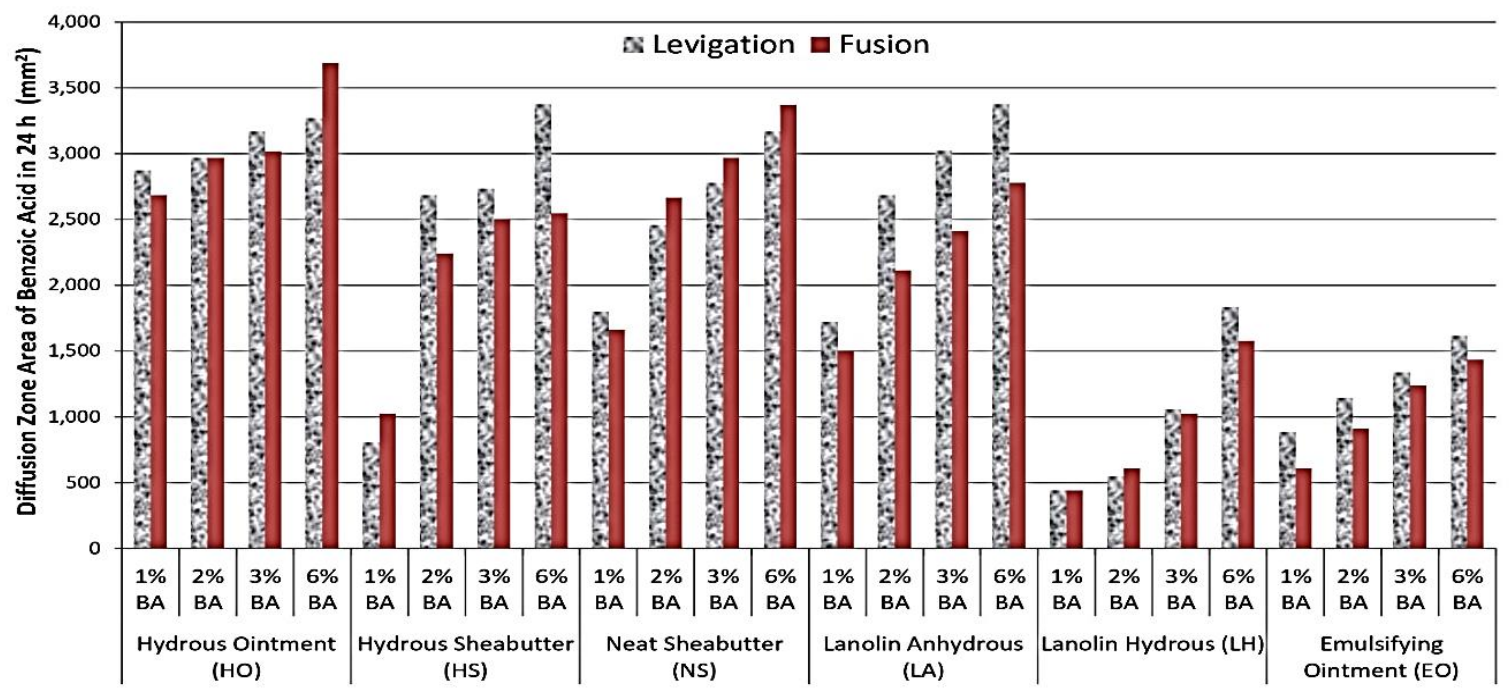

Figure 3: Benzoic Acid (BA) Quantities Released from Hydrophilic Ointment Bases 


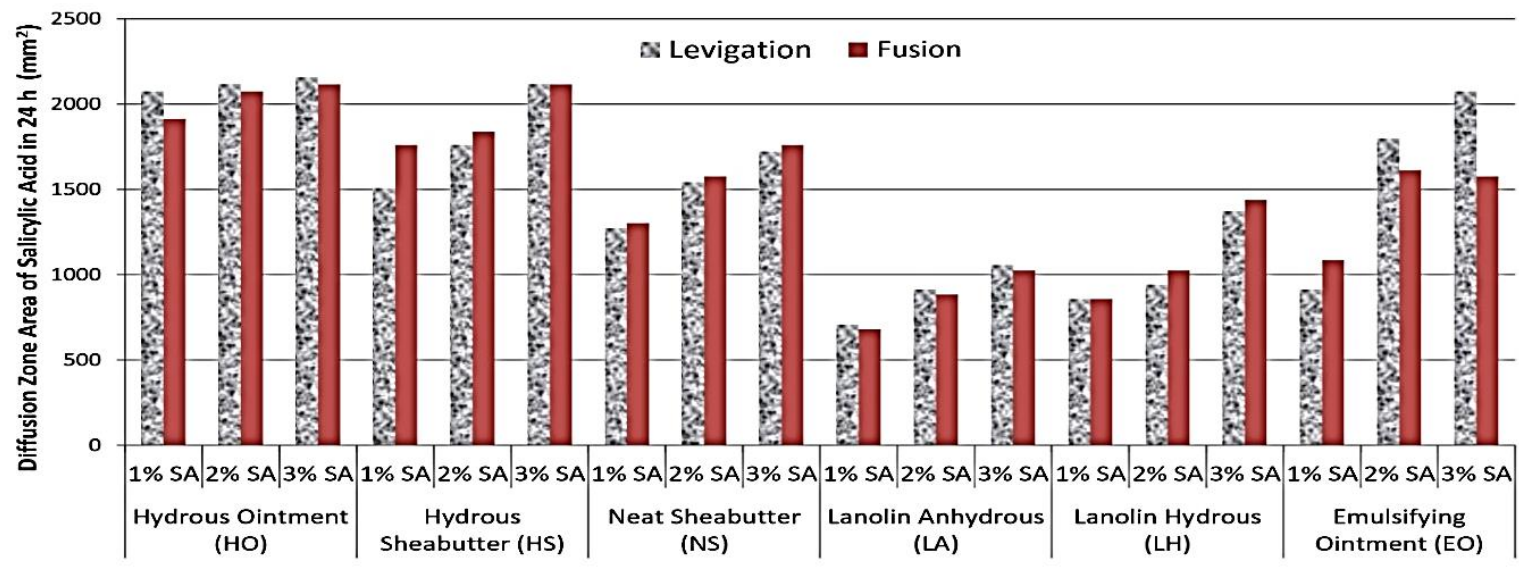

Figure 4: Salicylic Acid (SA) Quantities Released from Hydrophilic Ointment Bases

Table 4: Rates of release of Benzoic acid and Salicylic acid from $3 \% \mathrm{w} / \mathrm{w}$ medicated ointment in different bases

\begin{tabular}{llc|cc}
\hline & \multicolumn{2}{c}{ Medicament/ Preparation Method/ Release Rates $\left(\mathrm{mm}^{2} \mathrm{~min}^{-1 / 2}\right)^{\mathrm{d}}$} \\
\cline { 2 - 5 } Ointment Base & \multicolumn{2}{c|}{ Benzoic Acid } & \multicolumn{2}{c}{ Salicylic Acid } \\
\cline { 2 - 5 } Hydrous Ointment (HO) & $2.32(0.95)$ & $2.04(0.96)$ & $1.04(0.99)$ & $1.06(0.99)$ \\
Hydrous Sheabutter (HS) & $2.75(0.98)$ & $1.86(0.99)$ & $1.06(1.00)$ & $0.90(0.99)$ \\
Neat Sheabutter (NS) & $2.81(0.98)$ & $2.78(0.99)$ & $0.92(0.97)$ & $0.93(0.97)$ \\
Lanolin Anhydrous (LA) & $1.94(0.97)$ & $1.91(0.98)$ & $0.58(0.96)$ & $0.57(0.95)$ \\
Lanolin Hydrous (LH) & $0.42(0.98)$ & $0.54(0.97)$ & $0.68(0.98)$ & $0.64(0.99)$ \\
Emulsifying Ointment (EO) & $0.58(0.99)$ & $0.53(0.95)$ & $0.88(0.99)$ & $0.69(0.99)$ \\
\hline degression coefficients are shown in parentheses & &
\end{tabular}

Influence of ointment base on drug release Benzoic acid was released to significantly greater extents than salicylic acid in 24 h from HO, HS, NS, and LA comparing both medicaments at same concentrations; 1,2 , or $3 \%$, respectively $(p<0.01)$ (Figs 3 and 4 ). The benzoic acid amounts released from $\mathrm{HO}$, HS, and NS were comparable $(p>0.05)$ but significantly greater than the amounts released from other bases ( $L A, L H$, and EO) in the 24-h period $(p<0.01)$.

Salicylic acid, on the other hand, was released to significantly greater $(p<0.01)$ extents than benzoic acid from LH over $24 \mathrm{~h}$ at identical concentrations; 1,2 , and $3 \%$, respectively (Figs 3 and 4 ). But the extents of release of the two medicaments from EO were not significantly different $(p>0.05)$. The delivery of salicylic acid from five ointment bases occurred in significantly different amounts $(p<0.01)$ in the following descending order; $\mathrm{HO}>\mathrm{HS}>\mathrm{NS}>\mathrm{EO}>\mathrm{LA}$ but its release from $\mathrm{LA}$ and $\mathrm{LH}$ was comparable $(p>0.05)$. The trend of the magnitude of rates of release of the medicaments from different ointment vehicles (Table 4) was similar to that found for the extents of release of the medicaments. In summary, the three ointment bases, HO, HS and NS, demonstrated better release property for both medicaments than EO, LA and LH.

\section{Other presumed factors had no influence on drug delivery}

Different methods of ointment preparation, point differences in ointments' softening, various viscosity values under shear, and diverse water numbers of the bases did not produce significant observable trend effects on the rates of release of medicament from the medicated ointments studied $(p>0.05)$. No correlation was found between these parameters and the drug release rate data.

\section{Antimicrobial activities of Benzoic acid and Salicylic acid in aqueous solution}

Aqueous methanol solution of each medicament at $1 \% \mathrm{w} / \mathrm{v}$ and higher concentrations produced clear zones of inhibition against each test organism, while the 50\% aqueous methanol solvent alone (negative control) showed no inhibitory activities. Increase of the medicament concentrations from 1 through $4 \% \mathrm{w} / \mathrm{v}$ gave correspondingly larger inhibition zone sizes (Tables 5 and 6 ). 
Table 5: Antimicrobial activities of Benzoic acid in ointment formulation

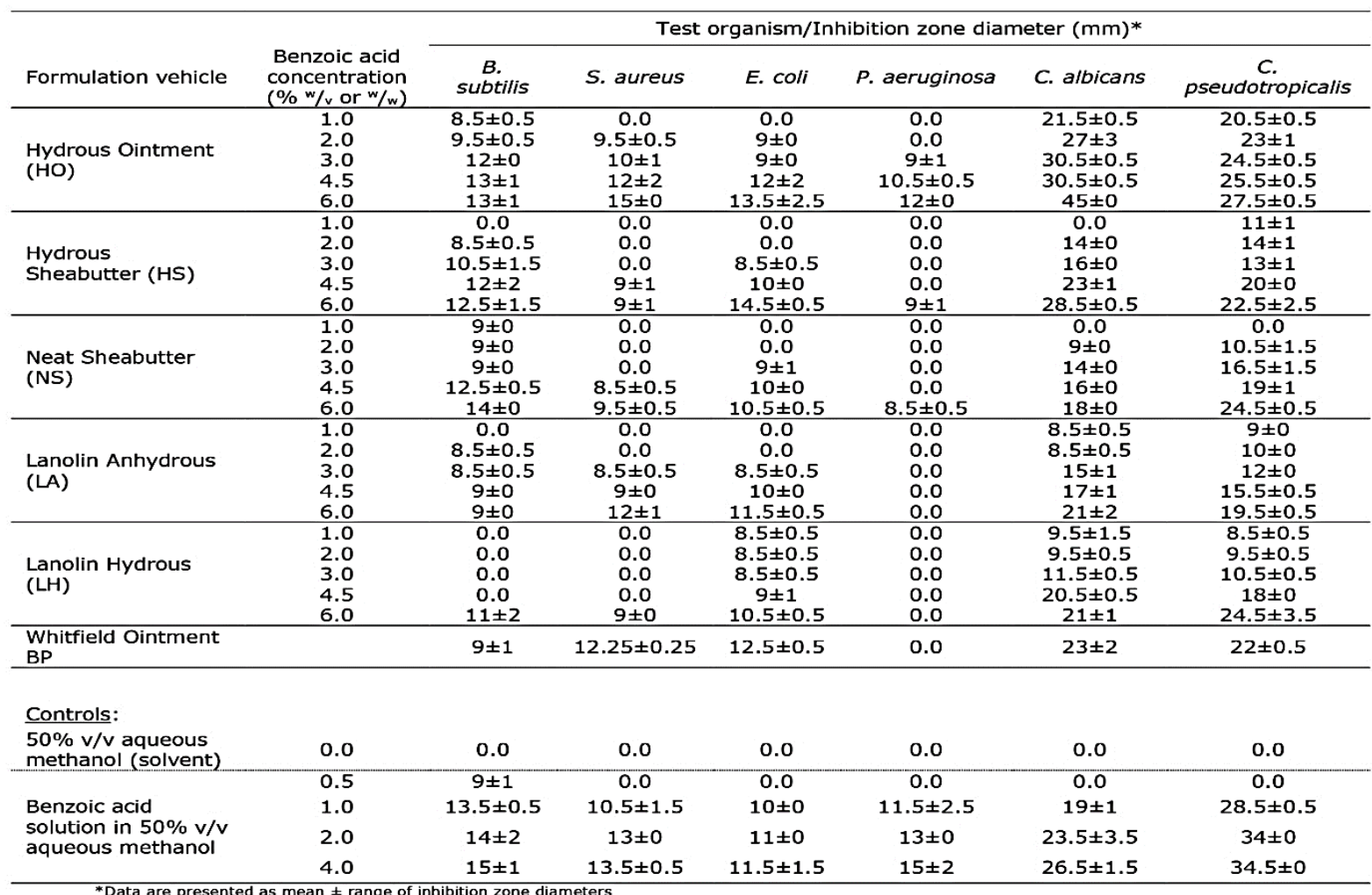

*Data are presented as mean \pm range of inhibition zone diameters
$0.0=$ Zero value: No inhibition

Table 6: Antimicrobial activities of Salicylic acid in ointment formulation

\begin{tabular}{|c|c|c|c|c|c|c|c|}
\hline \multirow[b]{2}{*}{ Formulation vehicle } & \multirow[b]{2}{*}{$\begin{array}{l}\text { Salicylic acid } \\
\text { concentration } \\
(\% \mathrm{w} / \mathrm{v} \text { or } w / w)\end{array}$} & \multicolumn{6}{|c|}{ Test organism/ Inhibition zone diameter $(\mathrm{mm})^{*}$} \\
\hline & & B. subtilis & S. aureus & E. coli & $\begin{array}{c}P . \\
\text { aeruginosa }\end{array}$ & C. albicans & $\begin{array}{c}\text { C. } \\
\text { pseudotropicalis }\end{array}$ \\
\hline $\begin{array}{l}\text { Hydrous Ointment } \\
\text { (HO) }\end{array}$ & $\begin{array}{l}1.0 \\
2.0 \\
3.0 \\
4.5 \\
6.0 \\
\end{array}$ & $\begin{array}{c}0.0 \\
10 \pm 1 \\
10.25 \pm 1.25 \\
12.5 \pm 0.5 \\
13.5 \pm 0.5\end{array}$ & $\begin{array}{c}10 \pm 0 \\
10.5 \pm 1.0 \\
11.75 \pm 0.75 \\
12.25 \pm 1.25 \\
15.75 \pm 0.75\end{array}$ & $\begin{array}{c}0.0 \\
11.25 \pm 0.25 \\
13.25 \pm 0.25 \\
13.75 \pm 0.25 \\
15.5 \pm 0.5\end{array}$ & $\begin{array}{c}0.0 \\
0.0 \\
9 \pm 0 \\
11.25 \pm 0.25 \\
13.25 \pm 1.25\end{array}$ & $\begin{array}{c}8.5 \pm 0.5 \\
17 \pm 0.5 \\
19.5 \pm 0 \\
21.25 \pm 0.25 \\
23.5 \pm 0.5\end{array}$ & $\begin{array}{c}0.0 \\
11 \pm 0 \\
14.5 \pm 0.5 \\
16.25 \pm 1.25 \\
17.75 \pm 0.75\end{array}$ \\
\hline $\begin{array}{l}\text { Hydrous Sheabutter } \\
\text { (HS) }\end{array}$ & $\begin{array}{l}1.0 \\
2.0 \\
3.0 \\
4.5 \\
6.0\end{array}$ & $\begin{array}{c}0.0 \\
9 \pm 0 \\
9.5 \pm 0.5 \\
11 \pm 1 \\
14 \pm 0\end{array}$ & $\begin{array}{c}9 \pm 0 \\
9.75 \pm 0.75 \\
12.25 \pm 0.75 \\
12.75 \pm 1.25 \\
16 \pm 0\end{array}$ & $\begin{array}{c}0.0 \\
9 \pm 0 \\
10.5 \pm 1.5 \\
11.75 \pm 0.25 \\
16.75 \pm 1.75\end{array}$ & $\begin{array}{c}0.0 \\
0.0 \\
9 \pm 0 \\
12.25 \pm 0.25 \\
13.5 \pm 0.5\end{array}$ & $\begin{array}{c}9 \pm 0 \\
18.5 \pm 0 \\
23.5 \pm 1.0 \\
26 \pm 1 \\
28.5 \pm 1.0\end{array}$ & $\begin{array}{c}0.0 \\
16 \pm 1 \\
18 \pm 0.5 \\
19 \pm 0.5 \\
23.25 \pm 0.75\end{array}$ \\
\hline $\begin{array}{l}\text { Neat Sheabutter } \\
\text { (NS) }\end{array}$ & $\begin{array}{l}1.0 \\
2.0 \\
3.0 \\
4.5 \\
6.0\end{array}$ & $\begin{array}{c}0.0 \\
8.5 \pm 0.5 \\
10 \pm 1 \\
10.5 \pm 0.5 \\
12.25 \pm 0.25\end{array}$ & $\begin{array}{c}11 \pm 1 \\
11.5 \pm 0.5 \\
13 \pm 0 \\
13.25 \pm 0.25 \\
15.25 \pm 0.25\end{array}$ & $\begin{array}{c}9.25 \pm 1.25 \\
12 \pm 0 \\
12.5 \pm 0 \\
14.75 \pm 2.25 \\
16.75 \pm 1.75\end{array}$ & $\begin{array}{c}0.0 \\
9.5 \pm 1.5 \\
11.75 \pm 0.75 \\
12.75 \pm 0.25 \\
13 \pm 0\end{array}$ & $\begin{array}{c}0.0 \\
11 \pm 2 \\
14 \pm 1 \\
15.5 \pm 0.5 \\
17.75 \pm 0.25\end{array}$ & $\begin{array}{c}0.0 \\
8.5 \pm 0.5 \\
9.5 \pm 0.5 \\
13.75 \pm 0.75 \\
16 \pm 0.5\end{array}$ \\
\hline $\begin{array}{l}\text { Lanolin Hydrous } \\
\text { (LH) }\end{array}$ & $\begin{array}{l}1.0 \\
2.0 \\
3.0 \\
4.5 \\
6.0\end{array}$ & $\begin{array}{l}0.0 \\
0.0 \\
0.0 \\
0.0 \\
9 \pm 0\end{array}$ & $\begin{array}{c}0.0 \\
0.0 \\
0.0 \\
8.5 \pm 0.5 \\
8.5 \pm 0.5\end{array}$ & $\begin{array}{c}0.0 \\
0.0 \\
0.0 \\
8.5 \pm 0.5 \\
9.75 \pm 0.75\end{array}$ & $\begin{array}{l}0.0 \\
0.0 \\
0.0 \\
0.0 \\
0.0\end{array}$ & $\begin{array}{l}0.0 \\
0.0 \\
0.0 \\
0.0 \\
9 \pm 0\end{array}$ & $\begin{array}{c}0.0 \\
0.0 \\
0.0 \\
9 \pm 0 \\
9.5 \pm 0.5\end{array}$ \\
\hline $\begin{array}{l}\text { Whitfield Ointment } \\
\text { BP }\end{array}$ & & $9 \pm 1$ & $12.25 \pm 0.25$ & $12.5 \pm 0.5$ & 0.0 & $23 \pm 2$ & $22 \pm 0.5$ \\
\hline
\end{tabular}

Controls:

\begin{tabular}{lccccccc}
$50 \% \mathrm{~V} / \mathrm{v}$ aqueous & 0.0 & 0.0 & 0.0 & 0.0 & 0.0 & 0.0 \\
methanol (solvent) & 0.5 & $8.5 \pm 0.5$ & 0.0 & 0.0 & 0.0 & 0.0 & 0.0 \\
\hline Salicylic acid & 1.0 & $9 \pm 1$ & $8.5 \pm 0.5$ & $12 \pm 0$ & $8.5 \pm 0.5$ & $9 \pm 1$ & $9.75 \pm 0.25$ \\
solution in $50 \% \mathrm{v} / \mathrm{v}$ & 2.0 & $10.75 \pm 1.75$ & $9 \pm 0$ & $14.5 \pm 0.5$ & $10.5 \pm 0.5$ & $14 \pm 1$ \\
aqueous methanol & 4.0 & $15 \pm 0$ & $12.5 \pm 0.5$ & $16 \pm 0$ & $12 \pm 1$ & $21.75 \pm 1.25$ & $16 \pm 0$ \\
\hline
\end{tabular}




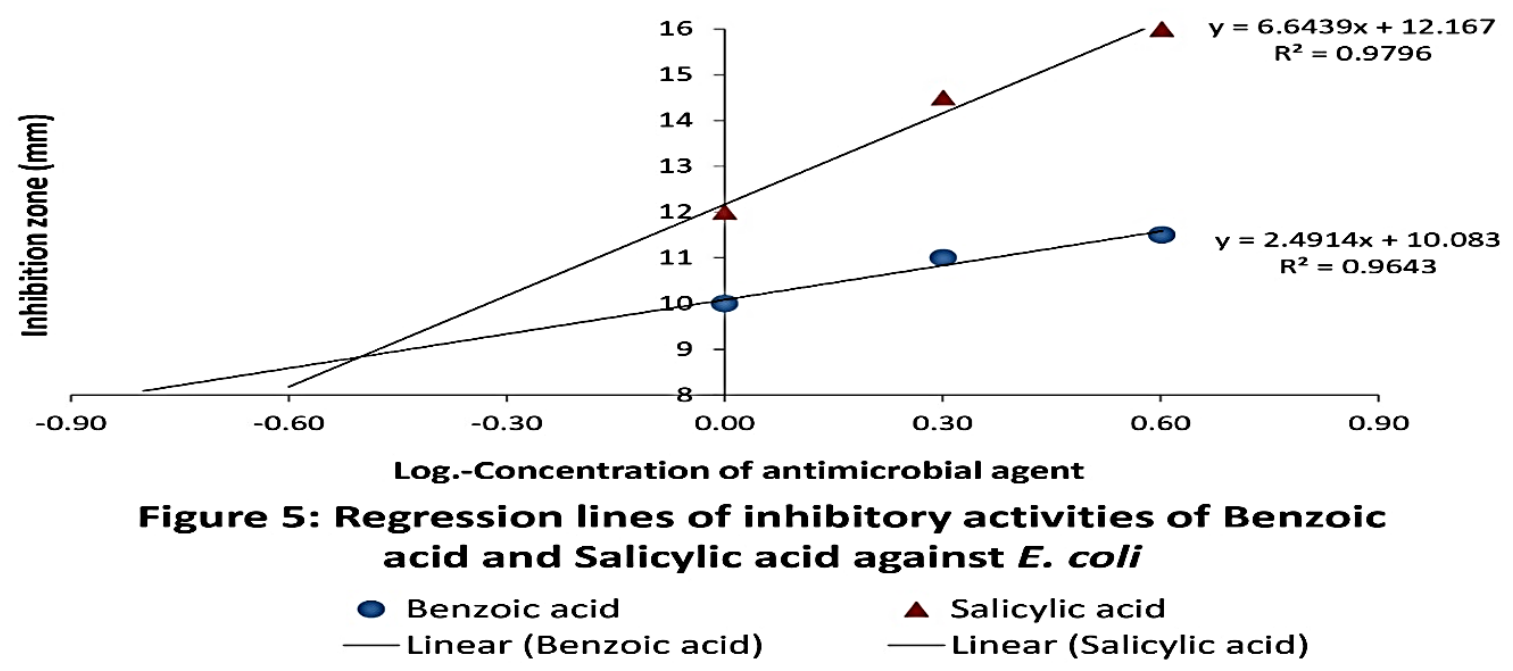

Table 7: Minimum Inhibitory Concentration of Benzoic acid and Salicylic acid against selected organisms

\begin{tabular}{lcc}
\hline & \multicolumn{2}{c}{$\begin{array}{l}\text { Medicament/ Minimum inhibitory } \\
\text { concentration (MIC) (mg/mL) }\end{array}$} \\
\cline { 2 - 3 } Organism & Benzoic acid & Salicylic acid \\
\hline Candida pseudotropicalis & 0.072 & 7.09 \\
Candida albicans & 1.25 & 9.43 \\
Escherichia coli & 1.46 & 2.36 \\
Pseudomonas aeruginosa & 2.58 & 7.94 \\
Staphylococcus aureus & 2.70 & 10.00 \\
Bacillus subtilis & 2.28 & 5.65 \\
\hline
\end{tabular}

Fig 5 illustrates that the logarithm values of the MICs of benzoic acid and salicylic acid against $E$. coli, obtained from regression lines plotted for the medicaments' inhibitory activities, were -0.83 and -0.62 respectively, leading to derivation of the MIC values of $0.146 \%$ and $0.236 \% \mathrm{w} / \mathrm{v}$ (i.e. 1.46 and $2.36 \mathrm{mg} / \mathrm{mL}$ ) respectively. Each MIC value for the medicaments (Table 7) was similarly determined, being the antilogarithm value of the abscissa coordinate (medicament concentration) at the intercept of extrapolated regression line with the horizontal $(x-)$, or log.-concentration axis of the graph where $y=8.0 \mathrm{~mm}$ signifying the $8.0 \mathrm{~mm}$ agarwell diameter and which (MIC value) could be alternatively obtained by algebraic derivation from the relevant best-fit line equation (24). Because the MIC values showed the relative susceptibilities of the test organisms to the antimicrobial activities of the medicaments, they revealed the yeast cells ( $C$. albicans and $C$. pseudotropicalis) to be more susceptible than bacterial cells to benzoic acid and that $C$. pseudotropicalis was the more sensitive yeast strain (lower MICs: 0.072 and $7.09 \mathrm{mg} / \mathrm{mL}$ ) while $E$. coli was the most susceptible bacterial organism to both benzoic acid and salicylic acid (least MIC values: 1.46 and $2.36 \mathrm{mg} / \mathrm{mL}$ ) but $S$. aureus was the least sensitive bacterium tested, showing the highest MIC values: 2.70 and $10.00 \mathrm{mg} / \mathrm{mL}$ respectively (Table 7 ).

Antimicrobial activities of Benzoic acid and Salicylic acid in ointment products

Each medicament incorporated in different ointment bases at graded concentrations $(1-6 \% \mathrm{w} / \mathrm{w})$ exhibited clear inhibition zones of different sizes against the test organisms (Tables 5 and 6), while non-medicated bases (negative controls) showed no inhibitory activities. The medicament concentration, its MIC relative to each test organism and the properties of each base in each ointment preparation all interacted multifariously to determine the antimicrobial activity outcomes, summarized as follows;

The yeast cells were relatively more susceptible than the bacterial cells to the inhibitory action of each medicament in ointment product. $E$. coli was the most sensitive while $P$. aeruginosa was the least sensitive bacteria to the inhibitory action of salicylic acid as medicament in almost all the ointment bases. $P$. aeruginosa was also the least sensitive bacterium to benzoic acid as medicament in all the six ointment vehicles. 
However, the relative susceptibility of $E$. coli, $B$. subtilis, and $S$. aureus to benzoic acidmedicated ointments depended on the vehicle employed.

Comparison of drug release results to antimicrobial activities in ointment

Comparison of delivery propensities of the medicaments in ointment preparations to their antimicrobial activities, in parallel study toward elucidating correlations and contributing factors, gave the following results; two ointment bases, hydrous ointment (HO) and hydrous sheabutter (HS) were prominent as those from which the greatest amounts of the active principle, was released in the colorimetric drug delivery assay, and from which the largest inhibition zone sizes were demonstrated by the medicament. Next to $\mathrm{HO}$ and HS were neat sheabutter (NS) and emulsifying ointment (EO) of approximately equal ranking as regards antimicrobial activities, while lanolin hydrous (LH) and lanolin anhydrous (LA) were the least-performing vehicles.

While salicylic acid at 1,2 , and $3 \%$ $\mathrm{w} / \mathrm{w}$ concentrations in LH-based ointments was released to significantly greater measure than benzoic acid, salicylic acid yet exhibited poorer antibacterial and antifungal activities when compared to benzoic acid ointment products in the same vehicle. This vehicle (LH) was thus atypical with respect to the correlation of antimicrobial ointment activities with active-principle delivery propensity of vehicle. The antibacterial and antifungal activities of all the ointment product samples against the most sensitive organism species (E. coli and C. pseudotropicalis, respectively) were used for this analysis, which provided sufficient data for the comparison.

\section{Discussion:}

The efficacy of antimicrobial treatment of topical infections depends upon adequate release of the active principle(s) from ointment medication following application to skin or mucous membrane. Physical properties of the ointment vehicle largely determine efficiency of release of the active principle. This study has examined five hydrophilic ointment bases selected from among vehicles commonly used in research or preparation of medicated ointments $(25,26,27)$ as possible alternatives to emulsifying ointment (EO), for improved delivery of benzoic acid and salicylic acid in topical antimicrobial medication. Improvement of an existing formulation may well involve the selection of a superior vehicle on grounds of its better intrinsic qualities for required therapeutic application of the active principle (28).
In vitro release studies are useful and used for prospective drug delivery efficacy testing, to evaluate the relative performance of comparable formulations and elucidate interactions between the active substance(s) and the semisolid base in dermatological formulations development (29). The agar diffusion testing procedure is reputed to correlate significantly with absorption rate through the skin for solid medicaments dispersed in solid matrices $(30,31)$. The rates and extents of release of benzoic acid and salicylic acid from the investigated bases, determined in the study, integrated the medicaments' delivery profiles from the respective vehicles and from the agar medium.

Active principle of small particle size $(\leq 180 \mu \mathrm{m})$ was used in the study to aid its dissolution in the ointment matrix. However, the medicaments did not completely dissolve but were suspended (dispersed) in the base because their concentrations used $(6 \% \mathrm{w} / \mathrm{w}$ benzoic acid and $3 \% \mathrm{w} / \mathrm{w}$ salicylic acid; same as for the official Whitfield ointment) far exceeded their respective aqueous solubility, to engender dissolution in the aqua-porous phase of hydrophilic bases' matrix so that particulate dispersion ointment products resulted. Undissolved drug in a dispersion ointment serves as the reservoir from which more drug is dissolved as the minute amount in solution is liberated. Drug release from suspension-type ointments is reportedly influenced by its solubility, diffusion coefficient and concentration in the vehicle $(21,32)$. The latter factor was corroborated in this study. Considering this factor, an alternative approach to enhancing release and efficacy of the active principles could be by increasing their concentration or modifying their ratio used in the ointments formula (33). However, the highest concentration of the active principle tested in this study was fixed at $6 \%$ because salicylic acid in topical use is known to be destructive to dermal tissue above that value (34).

\section{Appropriate physical consistency supports ointment utility}

Physical stability is a requirement for topical semisolid medicinal products. The commonly used dermal antimicrobial ointments (e.g. of benzoic acid) are required to be soft and unctuous but stiff enough to remain in place when applied while protective ointments (e.g. zinc oxide paste) should be hard and stiff remaining in place when applied to abraded skin surfaces, and ophthalmic ointments are required to be the softest type $(35,36)$. The shear-thinning property of all bases used in the study was desirable, predicting ease of skin-surface spreading when the ointment would be 
applied (37), and thus supporting its therapeutic function as well as ensuring storage stability of the product (38).

Consistency durability of semisolid medications (creams and ointments) is however affected by heat, hence ointments are required to be always stored in a cool place. But on application to skin, warm human body temperature raises that of the applied ointment also to $37^{\circ} \mathrm{C}$. Therefore, temperature of $37^{\circ} \mathrm{C}$ is the appropriate and desirable softening or melting point for ideal ointments (37), so that the body temperature would enhance mobility of the incorporated medicament in the ointment vehicle and its release. All medicated ointments in this study showed softening point of $37^{\circ} \mathrm{C}$ or lower (Table 3 ) thus they met the suitability requirement. Also, the proximity of the softening and congealing points of each ointment base, being within $\pm 1^{\circ} \mathrm{C}$ (except for HS only) revealed that the internal three-dimensional network structure of the base, formed by its components (38), was much stable, withstanding disruptive effect of heat stresses applied.

On the other hand, the relatively higher vulnerability of HS base (made from NS by fusion) to heat stress was clearly attributable to its polymorphic character shown also by the significant drop in viscosity of its ointment products, accompanied with water-leaching. Sheabutter is known to exhibit polymorphism, transforming under thermal stress into weaker-texture (unstable) form having lower softening and melting point values than its stable form prior to heating (39). The physical consistency weakness of HS base evident in this study was, however, advantageous for drug release, in that it permitted more extensive delivery and greater antimicrobial activities of the incorporated medicaments than most other bases.

\section{Factors contributing to drug delivery in ointment}

Concentration of the active principle and appropriate selection of the ointment vehicle exert a prominent influence on the amounts and activities of the medicament released from ointment products, as this study has further substantiated. Benzoic acid and salicylic acid ointment formulated in four bases (HO, HS, NS, and EO) thus demonstrated drug release and antimicrobial activities superior to ointments made with other bases (LA or LH). Ignoring data of the latter two bases, trend-agreement was evident comparing the in vitro drug release data with the antimicrobial activity results. Other factors showing potential influence on delivery of antimicrobial medicaments in ointments studied were physical and formulation factors (heat stress and medicament intro- duced into vehicle, respectively), which altered ointment base consistency and stability in HS and NS-based products giving weaker-texture and lower-viscosity outcomes. The processing methods (fusion and levigation) were other factors, which caused polymorphism-related "bleeding" of the HSbased ointments. The HS bleeding was a reversal of water-incorporation into the base achieved at its compounding stage, and a form of syneresis. Syneresis is the separation of liquid (often the solvent phase) from polymeric materials (e.g. gels) constituted by aqueous and non-aqueous macromolecular units; a form of instability caused by shrinking of the three-dimensional gel network holding the liquid phase within the stable polymer structure (36).

Consistency alteration of ointment should expectedly influence its drug delivery rate particularly on ageing, because the rheological property determines the value of diffusion coefficient of the active substance in the formulation $(1,29)$. Incorporation of the medicament into ointment base in this study generally caused decrease, but sometimes increase, of viscosity of the resulting medicated ointments. Sinko (40) had stated that the rheological property of semisolid products is altered by incorporation of medicament into the vehicle, spreading the product on skin, or by milling operation. Yet, statistical comparison of the physical consistency parameter (viscosity values) of different ointment preparations of this study to release rates of their incorporated medicament was found to be not significant. Lack of significant impact of the rheological property of pharmaceutical semisolids on drug release has been similarly noted in earlier studies $(41,42)$.

\section{Conclusion:}

Benzoic acid exhibited stronger antimicrobial activities against most test organisms than salicylic acid in ointment preparations. There was correlation between release and antimicrobial activities of the medicaments in ointments produced using bases that permitted ample delivery of incorporated medicament. The drug delivery and activity appraisals increased with increase of drug concentration. Hydrous ointment and hydrous sheabutter bases demonstrated the highest levels of both antibacterial and antifungal properties, and the greatest amounts of the active principles released; followed by neat sheabutter and emulsifying ointment. Water number of the bases, or viscosity or heat-stress tolerance of bland or medicated ointments and method of ointment preparation did not demonstrate any direct influence on the rate of drug delivery from ointment vehicles. 


\section{References:}

1. Toro, J. L. Semi-solid dosage forms Compliance of semi-solid dosages to FDA Stage III Continuous Process Verification. FDA Watch 06.12.18; $6^{\text {th }}$ Dec. 2018. Contract Pharma. https://www.contractpharma.com/issues/201806-01/view fda-watch/semi-solid-dosageforms/ Accessed: 29 ${ }^{\text {th }}$ February 2020.

2. Linstrom, P. J., and Mallard, W. G. Benzoic acid, In: National Institute of Standards and Technology (NIST) Chemistry Web Book, NIST Standard Reference Database Number 69, Gaithersburg (MD), 2018

http://webbook.nist.gov Accessed: 08 February 2020.

3. International Chemical Safety Cards (ICSC): 0563. Salicylic acid: 2-Hydroxybenzoic acid, 0Hydroxybenzoic acid; CAS\#: 69-72-7; EC Number: 200-712-3; November, 1997. www.inchem.org/documents/icsc/icsc/eics0563. htm Accessed: 08 February 2020

4. Stuart, M. C., Kouimtzi, M., and Hill, S. R. World Health Organization (WHO) Model Formulary 2008 (Published 2009), Stuart, M. C., Kouimtzi, M., and Hill, S. R. (eds.) Department of Essential Medicines and Pharmaceutical Policies, World Health Organization, Geneva, 2009: 294296.

5. World Health Organization (WHO) Essential Medicines List $(\mathrm{EML}) .2^{\text {nd }}$ WHO Model List of Essential Medicines for Children, March 2010 update, Section 13.1: Dermatological medicines (topical): Antifungal medicines, 2010: 18.

6. World Health Organization (WHO) Essential Medicines Lists (EMLs). Changes (1977-2011) Comparative table of medicines on the WHO Essential Medicines List from 1977-2011. https://www.who.int/selection medicines/list/en/ Accessed: 27 March 2020

7. World Health Organization (WHO) Technical Report Series (TRS) 965. The selection of use of essential medicines: Report of the WHO Expert Committee, 2011 (including the $17^{\text {th }}$ WHO Model List of Essential Medicines and the $3^{\text {rd }}$ WHO Model List of Essential Medicines for Children), 2011: 74.

8. Odusote, M. O., and Mendie, U.E. Release of salicylic acid and benzoic acid from novel Whitfield's ointment formulation. Pharm World J. 1992; 9 (1): 20-22.

9. Woodford, R., and Barry, B.W. Penetration enhancers and the percutaneous absorption of drugs: an update. Cutan Ocul Toxicol. 1986; 5 (3): $167-177$.

10. Kaur, I. P., Rana, C., Singh, M., Bhushan, S., Singh, H., and Kakkar, S. Development and evaluation of novel surfactant-based elastic vesicular system for ocular delivery of fluconazole. J Ocul Pharmacol Ther. 2012; 28: 484-496.

11. Adegoke, A., Oladimeji, F. A., and Oyedele, A. O. Formulation of metronidazole suppositories with modified cocoa butter and shea butter bases for enhanced stability in tropical environment. J Pharm Res Dev Prac. 2016; 1 (1): $12-24$

12. Sieg, J. W. and Robinson, J. R. Vehicle effects on ocular drug bioavailability. J Pharm Sci. 1979; 68: 724-728.

13. Rafiee-Tehrani, M., and Mehramizi, A. In-vitro release of piroxicam from oil-in-water creams and hydroalcoholic gel topical formulations. Drug Dev. Ind. Pharm. 2000; 26: 409-414.

14. Oladimeji, F. A., Omoruyi, S. I., and Onyeji, C. $\mathrm{O}$. Preparation and in vitro evaluation of suppositories of halofantrine hydrochloride. Afr J Biotechnol. 2006; 5 (19): 1775-1780.

15. Schmitt, M., and Guentert, T. W. Influence of the hydrophilicity of suppository bases on rectal absorption of carprofen, a lipophilic nonsteroidal anti-inflammatory drug. J Pharm Sci. 1990; 79 (4): 359-363.

16. Oyedele, A. O., Igbeneghu, O. A., Alade, T. I., and Akinmusire, O. O. Moderate heat treatments enhance the quality of traded natural shea butter. Ife J Sci. 2020; 22 (1): 17-26.

17. British Pharmacopoeia (BP) Vol. I and II, London, the United Kingdom: The British Pharmacopoeia Secretariat. 2009: 6369.

18. Collett, D. M. Fundamental operations in compounding, In: Collett, D. M., and Aulton, M. E. (eds.). Pharmaceutical Practice, Chapter 4; Churchill Livingstone, Longman Singapore Publishers Ltd, Singapore, 1990: 21-28.

19. Adegboye, T. A., and Itiola, O. A. Physical and release properties of metronidazole suppositories. Trop J Pharm Res. 2008; 7 (1): $887-$ 896.

20. Konning, G. H., and Mital, H. C. Sheabutter V. Effect of particle size on release of medicament from ointment. J Pharm Sci. 1978; 67 (2): 374376.

21. Onaga, I. C., and Odusote, K. O. A preliminary study of drug release characteristics of palmkernel oil in topical formulations: A comparative evaluation. Nig J Pharm. 1988; 5 (19): 171-175.

22. Kalam, W. A., Humayun, M., Parez, N., Yadav, S., Garg, A., Amin, S., Sultana, Y., and Ali, A. Release kinetics of modified pharmaceutical dosage forms: A review. J Pharm Sci. 2007; 1: 30-35.

23. Medu, E. O., Idowu, T. O., Oyedele, A. O., Adesanya, S. A., Ogundaini, A. O., and Onawunmi, G. O. Antimicrobial activity of eleagnine isolated from the seed cotyledons of Chrysophyllum albidum. Nig J Nat Prod Med. 2016; 20: 27-34.

24. Oyedele, A. O., Lamikanra, A., and Orafidiya, L. $O$. Physical and antibacterial characteristics of the volatile oil of Hemizygia welwitschii (Rolfe). Phytother Res. 1992; 6: 224-226.

25. Ayres, J. W., and Laskar, P. A. Diffusion of benzocaine from ointment bases. J Pharm Sci. 1974; 63: 1402-1406.

26. Kubis, A. Studies on the release of solubilized drugs from ointment bases, Part 5: Influence of the volume of disperse phase on liberation of chloramphenicol from emulsifying ointments. Pharmazie. 1980; 35 (12): 788-789.

27. Oyedele, A. O., John, O. O., Ogungbemi, H. O., and Olateju, S. O. Ocular tolerance and in-vitro release of chloramphenicol in prospective eye ointment bases. Int J Pharm Pharm Sci. 2015; 7 (11): 306-311.

28. Nwoko, V. E. Semi solid dosage forms manufacturing: Tools, critical process parameters, strategies, optimization and validation. Scholars Acad J Pharm. 2014; 3 (2): 153-161.

29. Jankowski, A., Dyja, R., and Sarecka-Hujar, B. Dermal and transdermal delivery of active substances from semisolid bases. Indian J Pharm Sci. 2017; 79 (4): 488-500.

30. Higuchi, T. Rate of release of medicaments from ointment bases containing drugs in suspension. J Pharm Sci. 1961; 50: 874-875.

31. Higuchi, T. Mechanism of sustained action medication: theoretical analysis of rate of release of solid drugs dispersed in solid matrices. J Pharm Sci. 1963; 52: 1145-1149.

32. Salama, H. A., Ghanem, A. H., and Zein-ElDeen, E. On the diffusion of chloramphenicol from oleaginous ointment bases. Pharmazie. 1980; 35 (12): 769-771.

33. Gooskens, V., Ponnighaus, J. M., Clayton, Y., Mkandawire, P., and Sterne, J. A. Treatment of superficial mycoses in the tropics: Whitfield's ointment versus clotrimazole. Int J Dermatol. 1994; 33 (10): 738-742.

34. Furman, B. L. Salicylic acid, in Reference Module in Biomedical Sciences, Elsevier Inc. 2018 https://doi.org/10.1016/B978-0-12-8012383.97758-4 Accessed: 19 ${ }^{\text {th }}$ March 2020 
35. Colo, S. M., Herh, P. K. W., Roye, N., and Larsson, M. Rheology and the texture of pharmaceutical and cosmetic semisolids. Amer Lab. 2004; 36 (23): 26-30.

36. Florence, A. T., and Attwood, D. Physicochemical principles of pharmacy, $4^{\text {th }}$ edn., Chaps. 8 \& 12: Polymers and macromolecules; and in vitro assessment of dosage forms, Pharmaceutical press, London. 2006: 273-327, 463-478.

37. Park, E., and Song, K. Rheological evaluation of petroleum jelly as a base material in ointment and cream formulations: Steady shear flow behavior. Arch Pharm Res. 2010; 33 (1): 141150.

38. Pena, L. E., Lee, B. L., and Stearns, J. F. Secondary structural rheology of a model
Mital, H. C., and Dove, F. R. The study of shea butter 1. Physico-chemical properties. Planta Med. 1971; 20: 283-288.

40. Sinko, P. J. Martin's physical pharmacy and pharmaceutical sciences, $5^{\text {th }}$ ed. Chap. 20: Rheology, Lippincott Williams \& Wilkins, New Delhi. 2006: 561-583.

41. Havemeyer, R. N. The measurement of consistency as a rheological property of ointments. J Amer Pharm Assoc. 1956; 45 (2): 121-124.

42. Sanna, V., Peana, A. T., and Moretti, M. D. L. Development of new topical formulations of diphenhydramine hydrochloride: in vitro diffusion and in vivo preliminary studies. Int $\mathrm{J}$ Pharm Tech Res. 2010; 2: 863-869. 